\title{
Grundtvig og Søren Kierkegaard
}

\author{
Af Hellmut Toftdahl
}

I min bog: »Kierkegaard først - og Grundtvig så« har jeg søgt at måle Grundtvig med kierkegaardsk alen og Kierkegaard med grundtvigsk alen. Det er resultatet af denne konstellations ene halvdel: Grundtvig i lys af S. Kierkegaard, jeg i denne artikel vil gøre rede for, idet jeg specielt vil søge at anvende en moderne fremmedgørelsesproblematik som den fælles referensramme, der er nødvendig, om en konfrontation mellem to så forskellige personligheder skal føre en til sammenligning.

Jeg har ingen ambitioner om at omstøde den hidtidige Grundtvig-forsknings resultater, men jeg er tilfreds, hvis blot mine synspunkter vil kunne bidrage til at nuancere opfattelsen af Grundtvigs personlighed, og måske rokke lidt ved fastgroede etiketter.

$\mathrm{Nu}$ har forskningen jo inddelt Grundtvigs produktion ud fra en række kriterier, som er væsentlige for forståelsen af forfatterskabet, og som pædagogisk set har den store fordel, at det mægtige forfatterskab bliver nogenlunde håndterligt. Det kan derfor synes at være en tilsnigelse, når jeg taler om én Grundtvig, men denne fremgangsmåde er legitimeret med min metode, som er inspireret af fænomenologien. Fænomenologien er læren om det værendes væsen, og dens metode er at afdække jeg'ets møde med verden ved at redegøre for de ontologiske betingelser, hvorunder jeg'et realiserer sin eksistens. Amerikaneren Rollo May's foredrag »Eksistentiel psykologi« har påpeget denne psykologis anvendelighed til forståelse af litterære frembringelser. Fænomenologien betragter med Heidegger den menneskelige eksistens som en »In-derWeltsein« og en »Sein-zum-Tode«: mennesket er kastet ind i verden uden tilhørspunkter og med viden om døden som det eneste sikre. I denne menings-løse tilværelse må mennesket realisere sig som en meningsskabende eksistens, og dets tanker og frembringelser må opfattes som resultater af denne meningsskabende proces. 
Verden eksisterer ikke som en objektiv kendsgerning, men bliver bestandig til i en dobbeltimplikation mellem subjekt og objekt, så det klassiske skel mellem subjekt og objekt er en illusion. Verden er bestandigt et produkt af individets virksomhed, og når der specielt er tale om en forfatter eller filosof kan man derfor opfatte hans værk som et udtryk for hans orientering i tilværelsen, værket er en måde at have verden på.

En sådan betragtningsmåde anvendt på Grundtvigs forfatterskab vil ikke isolere forskellige sider af hans virksomhed eller dele ham op i teologen, politikeren, kulturkritikeren og digteren, ej heller vil fænomenologen interessere sig for, hvad Grundtvig mente 1810,1825 eller 1832, da fænomenologen ikke blot interesserer sig for hvad en person mener, men mere hæfter sig ved det førbevidste, ureflekterede. Fænomenologen vil bestræbe sig for at møde Grundtvig så uhildet som muligt og ikke betragte ham som objekt for psykoanalyse eller systematisk videnskab, da enhver systematisk metodik forudsætter en forudfattet indstilling hos forskeren, som låser mødet mellem ham og Grundtvig fast $i$ ganske bestemte rammer: så får vi en redegørelse for historikeren, teologen eller digteren Grundtvig, men den Grundtvig som havde disse meninger om tilværelsen, forsvinder ganske bag alle disse meninger. Stiller man spørgsmål til Grundtvig som historiker, så får man kun svar fra historikeren Grundtvig, teologen får kun svar fra teologen Grundtvig osv. Det integrale menneske Grundtvig, som har formuleret sin teologi, sin poetik og sin historiefilosofi som svar på de spørgsmål han har stillet sig selv, dette integrale menneske er det, fænomenologien søger at nå ved at stille sig så åbent som muligt og undlade at isolere visse aspekter af Grundtvigs virksomhed. Fænomenologen forudsætter, at der foruden de mange meninger også findes et jeg, som ikke er identisk med disse meninger, at den egentlige valplads for individets kampe ikke foregår på det bevidste plan, hvor meningerne produceres, men findes på det førbevidste plan, hvor individet konstituerer sig selv som individ med absurditeten som en konstant trussel mod individets produktivitet. Fænomenologen koncentrerer derfor sine iagttagelser omkring forfatterens forhold til de såkaldte eksistentialer, dvs. de ontologiske vilkår, hvorunder ethvert menneske må realisere sin eksistens. Undersøgelsen af et forfatterskab eller et enkelt værk vil bagom det direkte udtrykte søge at vurdere forfatterens 
redelighed i blotlæggelsen af forfatterjegets oplevelse af de eksistentielle grundkategorier: tid-rum, liv-død, lys-mørke, fylde-tomhed, tyngde-lethed, horisontal-vertikal, og det er i vurderingen af denne redelighed at forfatterskabet står eller falder. Jeg vil nu kort ridse Grundtvigs forestillingsverden op i lys af det her sagte, og jeg vil mene, at træk, som herved afdækkes, går på tværs af de forskellige Grundtviger, som forskningen har uddestilleret; det er mit håb, at disse træk vil kunne tegne billedet af en værensform, der vil kunne accepteres som et grundliggende substrat bagom de torsoer, Grundtvigforskningen har fremstillet ved den systematiske kortlægning af hans produktion.

Et gennemgående begrebspar i Grundtvigs tænkning er modsætningen liv-død. Livet er meget vidtspændende i sine betydninger. Det er som de fleste af Grundtvigs begreber ladet med connotationer. Det er ikke blot det biologiske liv som modsætning til den biologiske død; det betegner menneskets tilværelse, når det lykkeligt opfylder sin plads i det menneskelige fællesskab. Liv, lys, styrke, glæde og fylde er nøje forbundne associationer som modsætning til døden. Død, ensomhedsfølelse, mørke, afmagt, fortvivlelse og tomhed hører sammen. Døden er mærkbar i alt menneskeligt samliv; den er de opløsende kræfter, som resulterer i jeg'ets isolation fra Gud og næsten. I dag kalder psykologer fænomenet for depression; moderne filosoffer kalder det fremmedgørelse.

For Grundtvig er menneskelivet en valplads, hvor disse uforsonlige magter konkretiseret i forestillingen om Gud og Djævelen kæmper om herredømmet. Hvor Gud sejrer, er der liv og lys; hvor Djævelen sejrer råder død og mørke. Denne kamp vil vare ved indtil dommedag, hvor Gud opnår endelig sejr.

Denne dualisme gennemtrænger Grundtvigs tænkning, og den får konsekvenser for både hans teologi og hans etik, så også begreberne sandhed-løgn indgår i den nævnte række af fundamentale eksistensmodsætninger. Sandhed og løgn er således ikke først og fremmest et spørgsmål om ret eller uret, men snarere om væren eller ikke-væren; at være i sandhed betyder slet og ret at være til som helt menneske; at være i løgn betyder at være til på uholdbare forudsætninger. Et sådant dualistisk verdensbillede forudsætter troen på, at der i tilværelsen findes modsætninger, som er absolutte og uforenelige: at der med andre ord findes modsætninger, som 
vi kan tage stilling til med et entydigt ja eller nej. Denne dualisme fandt Grundtvig udtrykt i biblens ord om, at din tale skal være ja, ja og nej, nej; og på et meget tidligt tidspunkt (1813) fandt han i modsigelsens grundsætning et objektivt korrelat til denne subjektive overbevisning om det Ondes absolutisme, som han blev belært om ved dyrekøbt personlig erfaring under krisen 1810 . Grundtvig opfattede ikke logikken som en formel leg med begreber. Hans begreber modsvares altid af personlig oplevelse, og derfor kunne han ikke acceptere den moderne efter-kantianske tænkning, der uforpligtende præsterede det kunststykke at mediere alle modsætninger, også de eksistentielle; for ham var der modsætninger, som umuligt lod sig forene, og når romantikerne kunne bevise, at det onde var nødvendigt for det godes eksistens, var det for Grundtvig kun tomt hjerne-spind, som ville forudsætte, at Djævelen gik Guds ærinde og var nødvendig for Guds eksistens.

Indenfor kirken er det samme princip udtrykt i forsagelsen og trosbekendelsen, hvormed den kristne jo frasiger sig det onde og bekender sig til det gode. Modsigelsens grundsætning blev sammen med den "mageløse opdagelse « af trosbekendelsen og de personlige oplevelser af synden et vidnesbyrd om den fundamentale modsætning mellem sandhed og løgn. På det intellektuelle plan betyder denne "Tankens Grundlov« at menneskets tanker bindes, og at der vil gå opløsning i dets tanker om alt åndeligt, hvis denne lov ikke respekteres. Man kan sige, at Grundtvig sætter den fri tanke en grænse ved hjælp af netop denne tanke; han erkender, at der er tanker, som er farlige for individets beståen, og det er hans overbevisning, at individet selv er i stand til at holde de negative tanker borte ved en sådan bevidst fortrængning. Denne overbevisning kom til at danne de psykologiske forudsætninger for hans kristendom, der forlener det menneskelige liv med en gnist af den guddommelige sandhed. Et typisk Grundtvig-citat fra Theologisk Månedsskrift 1825 (bind 2, s. 98-99) vil belyse dette:

"jeg tror paa en Gud, som er den lyslevende Sandhed $i$ egen Person, thi om Ham er det vist, at han vil gjøre alt Mueligt, for at føre Folk til SandhedsErkjendelse, og, ved at skabe Verden, har Han dog i det Mindste unægtelig beviist, at Han kan gjøre meget Meer, end vi forstaae«.

Grundtvigs gudstro hænger altså nøje sammen med - er et udtryk 
for - hans behov for værdidifferenser i tilværelsen. Gud står som garant for de modsætninger, som er nødvendige for at individet kan realisere sig selv i valget af det Gode. Gennem samvittigheden har mennesket kontakt med Gud, og det ligger op til det enkelte menneske selv, om det vil tro på samvittighedens vidnesbyrd i den givne valgsituation. Grundtvig lægger altså nok en vis frivillighed i valget, men individets afgørelse kan ikke være vanskelig at træffe, når det modsatte af samvittigheden på forhånd stemples som løgn og usandhed. Ved at gøre samvittigheden til sandhedens vidnesbyrd har han skabt et psykologisk holdepunkt for troen, som ikke holder for en dialektisk analyse. Jeg skal ikke komme nærmere ind på dette problem her, i min bog har jeg uddybet det ved hjælp af Kierkegaards kritik af Grundtvig. Jeg vil blot pointere, at troen hos Grundtvig har karakter af en psykosomatisk betinget redningsplanke fra afgørelsens ansvarlighed under det, Kierkegaard ville kalde åndens risiko. Der er ikke hos Grundtvig plads for den suspension af samvittigheden, som Kierkegaard i »Frygt og Bæven« har vist er nødvendig for åndsmennesket i undtagelsessituationer. I opfattelsen af samvittigheden er Grundtvig etiker i kierkegaardsk terminologi.

Mennesket er ikke selvstændigt hos Grundtvig. Tværtimod vil selvrådigheden dræbe samvittigheden sammen med alt andet sanseligt og kun efterlade den som en kraftesløs skygge, den, de tyske filosoffer har kaldt den praktiske fornuft, siger Grundtvig i 1825. (Th. Md. sst.)

Det er de enkelte øjeblikke af livsfylde og glæde, Grundtvig fortolker som nådegaver og som vidnesbyrd om en guddommelig sandhed afspejlet i det menneskelige. Mennesket er skabt i Guds billede ved samvittigheden, men ved syndefaldet (selvrådigheden) blev det skilt fra Gud og blev hjemfalden til dødens og mørkets magter. Men Gud blev menneske i Kristus for at sone vore synder og tale ord til os, hvorved vi kan frelses fra døden og genfødes og opelskes til det evige liv: »Kristus ... gik i Tvekamp med Dødens Fyrste... og vandt derved en afgørende Seier over Livets Fiende«, hedder det i en prædiken. (Korspr. s. 66.)

I Grundtvigs forestilling er dommedag (kampen mellem godt og ondt) og det evige liv universelle, ikke eksistentielle hændelser. Dommedag er ikke en personlig kamp i mennesket, men en hændelse i tid og rum, hvor Gud overtager pladsen som den kæm- 
pende. Gud frelser gennem Kristus mennesket fra de livsfjendtlige magter. Kristi ord havde vægt, de satte mennesker i gang, sendte bølger af aktivitet omkring ham som fra et stenfald $i$ vand. Hvis sproget opfattes som et udtryk for jeg-overskridelse, transcendens, så kan Kristus som "Guds-Ordet« opfattes som et eksempel på den fuldkomne transcendens. Kristus tog verden $\mathrm{i}$ besiddelse med sine ord; han mødte reaktion på sin aktion, mennesker reagerede på hans tale. Hans tale var det levende ord, som kunne få andre til også at komme ud over sig selv. Derfor kunne Kristus uddrive urene ånder af mennesker, som var groet fast i dæmonisk fortvivlelse. Denne skabelse $i$ ordet kan nutidige mennesker få del $\mathrm{i}$ ved at stilles ind $\mathrm{i}$ ordets og troens virksomhed i menigheden. Her virker Kristus som det levende Guds-Ord ved Helligånden i bekendelse, forkyndelse og lovsang. Ordets virkninger viser sig først og fremmest i hjertet, og ved at betegne hjertet som hele menneskelivets kilde giver Grundtvig talen om ordets virkning en særlig konkretion i form af psyko-somatiske kendetegn. I vekselvirkningen mellem mund og hjerte har den menneskelige kontakt sin grundform; det levende ord findes, hvor den talende er engageret ikke kun med intellektet, men også med sine følelser, "Hjertet« - altså der, hvor transcendensen mest nærmer sig Kristuslighed i den uforbeholdne udlevering af personen.

Opgaven bliver for det enkelte menighedsmedlem i nuet reduceret til at gå i kirke og blive optaget i menighedens fællesskab for at høre det Guds ord, som præsten postulerer virkelig er Guds ord. Her vil evangeliet virke nyskabende på mennesket, forudsat at præsten er i besiddelse af det levende ord, som er Helligåndens gave. Præstens ord bliver »henrivende Sang om den korsfæstede igjen opstandne Galilæer«, og præsteembedet bliver et privilegium, thi »- hjærtegribende Veltalenhed og henrivende Sang er ingen Kunst, man kan lære, men en fri Aandens Gave, man endog mister, saa snart man ej længer skjønner derpaa«. Men til gengæld vil menigheden også være prisgivet en sådan præsts oratoriske gaver, hvilket fremgår tydeligt af de termer Grundtvig anvender om den proces, der sker med mennesket $\mathrm{i}$ troen på ordet. Det er ord som "giennemtrænge «, "sammensmelte«, "giennemgløde«, "giennemstraale«. Præstens virke i menigheden bliver en slags åndelig voldtægt med deraf følgende psykiske tømmermænd, når seancen i kirken er forbi og nuet atter stiller sine krav til det enkelte med- 
lem af menigheden om individuel selvrealisering. (Prædikener i Frederikskirken $535 \mathrm{f}$ ).

Hengivelse til et andet menneskes oratoriske evner vil i mange tilfælde virke beroligende på et menneske, som har behov for jegforløsning. I forblændelsen af de store syner glemmes for en stund de eksistentielle problemer, som er forbundet med individets evne til selvstændig realisering af de givne muligheder. Men et selvstændigt tænkende individ må forholde sig skeptisk til det levende ord og derved spærre af for netop det levende ords egenart som ligger i: den momentane fortryllelse. For skeptikeren er det levende ord en form for demagogi.

Vi vil nu komme ind på Kierkegaards kritik af det levende ord og den mentalitet, som anvendelsen af dette forudsætter.

Kierkegaard og Grundtvig kendte faktisk hinanden personligt. Mens Kierkegaards fader endnu levede, kom Grundtvig en del i det kierkegaardske hjem, og Sørens broder, P. C. Kierkegaard blev en trofast grundtvigianer. De to mænds udtalelser om hinanden er præget af en umådelig usaglighed og, især for Kierkegaards dagbogsnotaters vedkommende, frækhed. Alene dette kunne tyde på, at de ikke har været hinanden ganske uvedkommende. Usagligheden skyldes simpelthen, at de ikke har haft tilstrækkeligt kendskab til hinanden i dybden. Dette røber den sparsomme litteratur, der findes i deres biblioteker af hinanden.

Kierkegaard omtaler i de første år, endnu inden forfatterskabet var egentlig begyndt, Grundtvig med omend ikke beundring, så dog med en vis form for anerkendelse af Grundtvigs person. Overfor en studiekammerat indrømmede Kierkegaard villigt, at Grundtvig »var et Geni, ja, en Genius, thi en Genius er den, der opdager noget, og det havde Grundtvig sikkerlig gjort «. ${ }^{1}$ Den ensomme, af kristelig overbevisning kæmpende unge Grundtvig, kunne Kierkegaard beundre, men når han slyngede sine visioner ud som store opdagelser, affærdiges han med, at han er »et Vrøvl ${ }^{2}{ }^{2}$

En gang, siger Kierkegaard, kunne man overfor Grundtvig have det indtryk: Dette ser jo ud til at blive et menneske, som i

1. EP I 1833-43 s. LIII.

2. Pap. $\mathrm{X}^{4} \mathrm{~A} 69$. 
sandhed vil eet. Men siden er han blevet bedærvet af vor tids onde, som kan betegnes ved ordet »både-og «, både det ene og det andet. Det at sidde i embede med et par 1000 rigsdaler - og så tillige ville være et slags apostel, det er selvmodsigende, ja, det er "Barnestreger, som ikke bliver mere Alvor ved Hjælp af optrukne Bryn, rynket Pande, norsk Accent, Snurren paa R, og den øvrige Grundtvigske Affektation $\ll^{3}$ Kierkegaard forarges altså over, at Grundtvig var i stand til at forene sit ideale virke med et levebrød.

Allerede ved slutningen af 1830erne synes Kierkegaard, at Grundtvig har forladt den prædikenform, som bar vidnesbyrd om en kærnefuld forkyndelse. Efter et af sine første - måske endda det første besøg i Vartov kirke, er Kierkegaard alt andet end opbygget ved Grundtvigs forkyndelse:

»Al Grundtvigs Prædiken er dog ikke andet end en idelig gjentaget Phantasiens Udvandring, saa at Benene aldrig kan følge med, en ugentlig Udtømmelse, ${ }^{4}$ siger Kierkegaard 1839 om den nys tiltrådte Vartovpræst; hans prædiken savnede det personlige krav og det mod, som tør lægge vægten på jeg'et.

Derefter bliver dagbogsnotaterne om Grundtvig stadig mere satiriske, ofte med stor bitterhed og ironi:

"Det dumme ved Grundtvig ... er at han altid vil have Sikkerhed paa Aand... Ved at tale mener han at frembringe saa stor Virkning. O! ja, især i Retning af det Dunkle. Forøvrigt kunde han maaskee ogsaa frembringe Virkning ved at staae paa Hovedet. Tilsidst bliver det at svede, at rynke Bryn, at slaae sig for Panden, at smile selvtillidsfuldt, at besvime synligt under Aandens Magt etc. et Beviis for Lærens Sandhed. ${ }^{5}$

Det er Grundtvigs vidtspændende fantasi og evne til med sine talegaver at holde en menneskemængde $\mathrm{i}$ ånde, der har irriteret Kierkegaard. Kierkegaard forbinder altid Grundtvigs fremtræden med støj, og denne støj kan gøre ham aldeles fortvivlet. Denne uvilje mod Grundtvigs udadvendte folkelighed må ses $\mathrm{i}$ forbindelse med Kierkegaards syn på alt, som har med mængde og publikum at gøre. Den enkelte forsvinder i publikum. Man må ikke

3. EP $1854-55,536$.

4. Pap. XI A 542 .

5. Pap. V A 94. 
tro, at Kierkegaard var modstander af menighedsbegrebet. Det var han kun, hvis menigheden blev til et publikum. I dagbøgerne har han nogle overvejelser over, hvad menighed betyder for ham: i menigheden eksisterer den enkelte aktivt som en kvalitet, men han kan også i ethvert øjeblik blive højere end menigheden, nemlig når »de andre falder af fra Ideen«.

Kierkegaards angreb på Grundtvig kan derfor ikke skyldes dennes betoning af fællesskabet $\mathrm{i}$ menigheden, men at han har gjort Guds menighed til et publikum ved at slå af på kravene til den enkelte, der glemmer sig selv under Grundtvigs poetiske og historiske syner: "I Forhold til det religiøse er al historisk Fremstilling Adspredelse. Tilhøreren kommer til at glemme sig selv over Luther og Solens Opgang, over den mageløse Opdagelse, som blev gjort i København. Men i Forhold til det religiøse er det negative at glemme sig selv og det positive at blive gjort selvvirksom... Falkeblik paa Verdenshistorien erstatter her ikke et besindigt Indblik i sig selv, de mageløse Opdagelser, om det saa var Krudtets, gør ikke Fyldest som Vederlag for Mangelen paa Selverkendelse og majeutisk Kunst i Forhold til andre ${ }^{6}{ }^{6}$

Grundtvig opfattede jo menigheden som en organisk helhed, der har været, er og altid vil være, hvor Guds ord høres i nadveren og dåben af levende mennesker. Kirken er altså for ham ikke en numerisk størrelse, men det kristne trosfællesskab, skabt ved dåben og omfattende alle, der ved trosbekendelsen bekender sig til deres dåbstros værdidifferentierende kraft.

For Kierkegaard var det værste ved kirken, at den gav medlemmerne af menigheden en falsk følelse af sikkerhed; derfor blev det hans kald at råbe alarm mod denne vildfarelse og foretage en radikal revision af, hvad det betyder at være kristen. Kierkegaard lægger vægt på, at vi modtager Kristus som det eksempel, vi ikke ligner, og som forsoneren, der er lutter barmhjertighed, når vi ydmyger os. Kristus-lighed nås ikke $\mathrm{i}$ dette liv, der kun er kamp og prøvelse, men først i evigheden, og derfor er menighedsbegrebet anvendt på dette liv en utålmodig forudgriben af evigheden; "Menigheden « hører ikke til i tiden, men i evigheden. Kierkegaards menighedsbegreb synes således eskatologisk, mens Grundtvigs menighed er Kristi virkelige konkrete forbindelse med verden, en di-

6. Pap. VI 410. 
stinktion som Henning Høirup ${ }^{7}$ har påpeget. Men jeg mener ikke, at Kierkegaards menighedsbegreb er eskatologisk, hvilket vil ses, når man analyserer hans evighedsbegreb. ${ }^{8}$ Evigheden er hos Kierkegaard ikke noget tidsbegreb, men en værensform, hvor tidsoplevelsen er elimineret, successionen ophævet, afstande erstattet af det indholdsfulde nærværende; evigheden er et stående nu. At menigheden hører evigheden til, betyder derfor, at menigheden opstår der, hvor det evige bliver til i tiden, altså hvor et menneske bliver »hin Enkelte«, der gør dobbeltbevægelsen, gen-tager. Det er med andre ord en menighed af individualister, Kierkegaard taler om, ikke en »mængde « som den grundtvigske vennekreds, der er organiseret i en art forbund. Kierkegaards menighed er en nuvarende forsamling af mennesker, der tilfældigvis på samme tid og sted har vendt sig med deres »evige Selv«: en "happening «, som i kierkegaardsk forstand må siges ikke at høre tiden, men evigheden til - evigheden $i$ tiden. Grundtvigs menighed bliver optaget i Kristus ved en fælles overenskomst mellem præst og menighed. Kierkegaards menighed opsøger Kristus sammen i efterligning af hans inderlighed. Det er en forskel i indre aktivitet og foruroligelse hos det enkelte medlem af menigheden.

Kierkegaard kan ikke forlige sig med det visionære, umiddelbare i Grundtvigs oplevelse af kristendommen, som giver sig udslag ikke bare $\mathrm{i}$ hans prædikener, men også i hans salmeproduktion. "Den brusende Grundtvig «, kender efter Kierkegaards mening slet ikke »den Fromhed, som egentlig er en stille Lidendes«, han mangler evnen til at tale og synge sagte og inderligt:

»Grundtvig er og var og bliver en Støiende, selv i Evigheden vil han være mig ubehagelig. Ikke som havde Grundtvig ikke gjennemgaaet noget, jo vist, men altid støjende. Det er noget Enkelt, der standser ham paa hans Vei, og saa gjør han et Spektakel som naar et Jernbanetog stødte an underveis. Den dybere, inderligere Smerte, der i stille Vemod forligte sig med Gud, kjender Grundtvig slet ikke, og just den er Psalmesangens ægte Tone. Grundtvig er en jodlende Friskfyr, eller en brølende Grovsmed «. ${ }^{9}$

7. Grundtvig-Studier, 1956, s. $17 \mathrm{f}$.

8. se eks. SV, 6,174 .

9. Pap. VIII ${ }^{1}$ A 487 . 
$\mathrm{Vi}$ vil nu søge at sammenfatte vore betragtninger over Kierkegaard og Grundtvig til en sammenlignende karakteristik:

Såvel Grundtvig som Kierkegaard var blevet opmærksom på en fare, som lå i den af ortodoksien påvirkede teologi: faren for at glemme mennesket i spekulationer over den rette lære om menneskelivet, og lade tænkning forhindre menneskelivet $\mathrm{i}$ at komme til udfoldelse. Grundtvig nåede gennem sine mange selvopgør frem til den opfattelse, at den oprindelige kristendom på utilladelig vis indsnævrede det menneskelige liv. Hans opgør gjaldt den lutherske ortodoksi og bodskristendommen, der betragtede livet her på jorden som et eksil, en pilgrimsfærd mod et andet og bedre liv i det hinsides. En sådan kristendom tager ifølge Grundtvig farven af det herværende liv og kraften fra kristendommens forkyndelse om syndsforladelse og forløsning. Heroverfor hævder Grundtvig, at fødselen går forud for dåben, skabelsen forud for forløsningen - han giver jordelivet berettigelse i sig selv, ikke som en omvej eller en hindring for det at blive kristen, men som en forudsatning for det kristne liv i bestandig vækst og udvikling. Kun hvor dette liv leves $\mathrm{i}$ sin fulde udstrækning, kan kristendommen findes: »Menneske først - og kristen så «.

Også Kierkegaards ærinde var at redde det menneskelige. Men han gør det på en mere differentieret måde end Grundtvig, hvilket hænger sammen med hans filosofiske skoling. Hans opgør gælder først og fremmest den af Hegel påvirkede tænkning, der kort kan karakteriseres som: overrefleksion, identificering af tænkning med væren. Kierkegaard taler ikke alment om det at være menneske i en eller anden social sammenhæng, som f.eks. Karl Marx.

Han er ontolog og taler derfor mest om eksistens og det at eksistere som enkeltindivid. Pseudonymet i "Afsluttende uvidenskabeligt Efterskrift « siger: "Min Hovedtanke var, at man i vor Tid formedelst den megen Viden havde glemt hvad det er at existere, og hvad Inderlighed har at betyde, og at Misforstaaelsen mellem Speculationen og Christendommen maatte lade sig forklare deraf «.10 Han forklarer videre, at han for at vise, hvad det vil sige at eksistere religiøst er gået så langt tilbage som muligt, nemlig til det at eksistere menneskeligt, thi "havde man glemt hvad det er at existere religieust, havde man vel ogsaa glemt, hvad det er at

10. SV, 9,208 . 
existere menneskeligt«. Hvad han her vil sige er altså: 1. at eksistens ikke kan forstås uden inderlighed, og 2. at den megen viden er en fare for eksistensen.

Der findes ifølge Kierkegaard én væsentlig opgave for mennesket: at eksistere $\mathrm{i}$ inderlighed. Men mennesket kan blive ledet bort fra denne opgave af den megen adspredelse, af al »Udvorteshedens Spektakel«. Som middel til adspredelse gælder også i udstrakt grad den megen viden, ${ }^{11}$ i særdeleshed fra Kierkegaards synspunkt den spekulative hegelske tænkning, men naturligvis enhver form for spekulativ tænkning. Kierkegaard så sig selv stå over for en almen flugt fra den inderlige eksistensform, så der næppe mere fandtes nogen forestilling om, hvad dette vil sige. Derfor er hans værker før kirkestormen mest eksistens-meddelelser, begyndende med den mest umiddelbare eksistensform, den æstetiske, over den etiske til den religiøse og den kristne. Han forelagde sine eksistens-meddelelser pseudonymt og undgik derved doceringens direkte meddelelse, fordi denne ville kunne foranledige modtageren til at tro, at han har modtaget viden; men meddelelse om det at eksistere og om inderlighed kan aldrig gives i form af viden; gør man det, vil man blot give spekulanten endnu mere stof til hans spekulative tilværelsessystemer og derved føre ham endnu længere bort fra inderligheden. Derfor har Kierkegaard fremlagt sine værker til afklaring for den enkelte, men uden at angive, hvorledes den enkelte finder løsningen på sit eksistensproblem. Man ser, hvorledes hans sigte ligner Grundtvigs: Grundtvig ville redde det menneskelige fra den religiøse spekulation ved at give det noget konkret: ordet ved sakramenterne og $\mathrm{i}$ det hele taget det levende ord i alt menneskeligt samvær fremfor død spekulation. Kierkegaard ville redde mennesket fra at fortabe sig i den spekulative tænkning. Men som vi har set, går Kierkegaards opgør dybere end Grundtvigs, fordi Grundtvig til dels løser opgaven ved dogmatik, dvs. ny spekulativ viden, mens Kierkegaard gennemhuller den spekulative systematisering ved hjælp af sin skarpe dialektik: logik anvendt med uhyre definitorisk energi.

På Grundtvigs og Kierkegaards tid var det gamle håndværkersamfunds opløsning allerede ved at være en realitet. Maskinerne

11. SV,9,29. 
var i færd med at holde deres indtog. Industrialderen var begyndt, hvor mennesker ser færdige varer glide ud af maskiner, som de ikke har nogen forestilling om selv at være ophav til. I de kommende hundrede år skulle maskinerne blive større og større, menneskene mindre og mindre. Produktionen af forbrugsgoder og -onder skulle blive så stor, at mennesket blev et redskab for produktionen og ikke omvendt. Det ny samfunds skabere og magthavere blev producenterne, som naturligvis skabte samfundet efter deres behov for maximalt forbrug, med køleskabe og dollargrin som status- og lykkesymbol. Resultatet skulle blive, at borgerskabet, kunstnerne og akademikerne blev hjemløse i dette samfund, som de ikke selv havde været med til at skabe. Åndslivet skulle blive stadig mere reflekteret, grundet på akademikernes isolering. Radikale tænkere væltede de gamle autoriteter: kirke, samfundsstøtter, familiefader, tradition, for til sidst at sidde med den tomme frihed til: alt og intet; for en frihed, der ikke engageres i en ufrihed, er som en uindløst veksel - en veksel på fremtiden. Resultatet er blevet, at mens det store flertal i dag nyder industrialderens produkter, er de intellektuelle stort set delt i to lejre: En konservativ resigneret, som dyrker absurditeten og fremmedgørelsen - og en oprørsk radikal, som nok erkender fremmedgørelsen og absurditeten, men som ikke har mistet troen på, at det er muligt at ændre samfundet: ikke dem selv, men det "manipulerede « massemenneske, som de moraliserende fordømmer for dets mangel på kritisk sans.

Fremsynede filosoffer i det 19. århundrede var klar over, at disse problemer ville melde sig i fremtidens samfund, hvor det personlige ville blive undertrykt af et stadig stærkere kollektiv. For Hegel, Marx, Kierkegaard og Nietzsche blev målsætningen: hvordan blive »sig selv« under den stigende trussel om personlighedens udslettelse, som lå i det ny samfund. Derfor er disse filosoffer stadig »moderne«, i den forstand, at deres problemstilling vedkommer mennesker $\mathrm{i}$ dag. I en vurdering af forholdet mellem Kierkegaard og Grundtvig vil det derfor være relevant at undersøge begges stilling til dette velfærdsproblem, som betegnes »fremmedgørelse«.

Sløk har bestemt oplevelsen af fremmedgørelsen som »verden der skifter ansigt, eller naturen, der vender mennesket ryggen, den pludselige og påtrængende indsigt, at man bliver fornægtet af 
verden, at man er uvedkommende, fremmed og uønsket « $;^{12}$ oplevelsen tilintetgør den pågældende $\mathrm{i}$ hans tilstedeværelse, gør ham til en afdød for omverdenen og fratager ham hans identitet. Selve udtrykket stammer fra Karl Marx, der anvendte det i en lignende betydning, men troede, at fænomenet ville forsvinde i det kommunistiske samfund, hvor mennesket vil have genfundet sit værd som skabende individ. Marx satte lighedstegn mellem menneskelig identitet og skabende selvudfoldelse, men overså, at mennesket $\mathrm{i}$ dets selvudfoldelse kan støde mod kræfter, som det ikke selv er herre over, og at det uvægerligt støder mod sådanne kræfter, hvis det udfolder sig uden begrænsninger.

P̊̊ dette punkt er det Kierkegaard bliver aktuel. Også han ser mennesket som en vilje til selvudfoldelse, men den areligiøse menneskelige eksistensform gror fast i fortvivlelse, sygdommen til døden, fordi mennesket under denne selvudfoldelse bliver mere og mere fremmed for sig selv, bliver en levende død uden identitet. Når mennesket således er tvunget ud i sin eksistens' fuldkomne frihed, den tilstand som er karakteriseret ved det berømte »Subjektiviteten er Sandheden ${ }^{13},{ }^{3}$ og han da fortvivler, da møder han Gud i den paradoksale erkendelse, at subjektiviteten som sandhed er usandheden. Mødet med Guden er uundgåeligt, fordi det er et paradoks at ville blive et selv, når man har erkendt, at man intet fast, objektivt erkendeligt selv har, og paradokset er netop Gud. For Kierkegaard er gudserkendelse en konsekvens af selverkendelsen; og fortvivlelsen, den levende afdøen, fremmedgørelsen er det tomrum, hvorfra en sådan selverkendelse resulterende i gudserkendelse udelukkende kan hentes. Ethvert forsøg på at finde en genvej er blot fortvivlelse. ${ }^{14}$

12. Johannes Sløk: »Eksistentialisme«, Kbh. 1964, s. 17.

13. SV,9,174.

14. jvf. Pap. $\mathrm{X}^{5}$ A 25: "- Det at afdø er det fordrede. Paa den anden Side er det noget, som Gud ikke kan tvinge et Menneske til. Thi om Gud end berøvede et Menneske Alt, sendte ham alle Lidelser paa Halsen, deraf fulgte ikke, at Mennesket afdøde; thi at afdø er en Akt af Frihed. Dog er det det fordrede. Man ser heraf, hvor fjern vor Opfattelse, som den er $\mathbf{i}$ Almindelighed, er fra det christelige; thi vi mener, naar det begynder med Lidelse, at vi blot skal holde ud, haabe, saa kommer der nok bedre Tider - o, hvilken uendelig Afstand fra det at afdø, frit at slippe det Jordiske«. 
Forholdet til Gud er altså ikke et spørgsmål om en ny spekulativ erkendelse. Det er et etisk krav til mennesket, som det selv vil, om at komme fri af undtagelsestilstandens forargelse og absurditetsfornemmelse. Gud er $i$ Kierkegaards teologi navnet på viljen til at skabe noget af sig $i$ stedet for at fortvivle; men det er en skabelse, som sker i kraft af det absurde, fordi mennesket i fortvivlelsen har erkendt sin intethed. Troen er derfor ikke nogen helbredelse for sygdommen til døden, men i troens lidenskab former man et selv på trods af fortvivlelsen, istedetfor at gå til grunde i denne. I modsætningen mellem tro og fortvivlelse opstår en spænding, og kriteriet på den sande troende er, at han kan udholde denne spænding hele livet og ikke søger beroligelse i en objektiv vished eller et andet menneskes oratoriske gaver. For den specielt kristne religiøsitet ${ }^{15}$ fremtræder da Kristus paradoksalt som en legemliggørelse i tiden af Guden, dvs. af viljen og den fuldkomne evne til at være et inderligt eksisterende selv. Gud er en ontologisk idé; denne idé fremtræder i Kristus legemliggjort, og det er det paradoksale: at en idé bliver til kød og blod. Kristus bliver da den sandhed, som den kristne møder i tilbagestødet fra sin isolation i subjektiviteten. Kristus gør subjektiviteten til usandheden. Kristus bliver et forbillede for den identitetsløse kristne, idet han ved at tænke sig samtidig med Kristus forsøger at efterleve dennes inderlige eksistensform; der er ikke tale om nogen objektiv beroligelse, da denne efterleven ikke kan specificeres ud i konkrete detailler til støtte for den enkelte i hans egen situation: de objektivt foreliggende historiske detailler vedrørende Kristi person er af underordnet betydning for den i Kierkegaards forstand kristne. At subjektiviteten bliver gjort til usandheden betyder ikke, at objektiviteten bliver til sandheden. Objektiviteten er ikke alternativet til subjektiviteten, men den ovennævnte spænding mellem subjektets tro og den objektive uvished.

Enhver genvej til kristendommen og altså til selverkendelse

15. Religiøsitet $\mathrm{B}$ er den kristne religiøsitet: individet er $\mathrm{i}$ usandhed og støder mod det dobbelte paradoks (SV,9,174). Førend der kan blive tale om at erkende »det dialektiske $\mathrm{B}$ « (SV,10,226), må Religiøsitet A være til stede: det er hedenskabets religiøsitet, som Sokrates repræsenterede, enkelt-paradokset (at den evige idé forholder sig til en eksisterende) uden den Gud i tiden, der er det forargende dobbelt-paradoks, som kristendommen postulerer (at den evige ide er blevet eksisterende i kød gennem Kristus). 
uden om fortvivlelsen er ifølge Kierkegaard ikke mulig. Ikke engang den lykkelige er fri for fortvivlelsen, om han end kan synes at være det, »thi langt, langt inde, inderst inde i Lykkens skjulteste Forborgenhed, der boer ogsaa Angesten, som er Fortvivlelsen; den vil saa gjerne have Lov til at blive derinde, thi det er Fortvivlelsen dens kjereste, dens meest udsøgte Sted at boe: inderst inde $\mathrm{i}$ Lykken. Al Umiddelbarhed er trods sin illusoriske Tryghed og Ro Angest «, hedder det i »Sygdommen til Døden«. ${ }^{16}$

På disse punkter rammer Kierkegaard hårdt mod Grundtvig. Hvis fortvivlelsen, fremmedgørelsen er et nødvendigt nåleøje til den inderlige kristendom, og det vil jo i kierkegaardsk opfattelse sige enhver inderlig tilværelsesform overhovedet - hvis dette er en uomgængelig kendsgerning, vil der udfra en sådan synsvinkel være meget at indvende mod såvel Grundtvigs teologi som hele hans kulturprogram.

Først og fremmest mangler den skarpe gennemtænkning i Grundtvigs vidtrækkende målsætninger. Han oprejser skabelsen, mennesket, befriet for bodskristendommens tryk. Hans sekulariseringsbestræbelser og folkeoplysning må ses som et led i den hensigt at få folk til at leve et naturligt menneskeliv. Men som Kierkegaard har påpeget mangler den kritiske instans i hans sekularisering, thi sekularisering som blot umiddelbar foranstaltning, der doceres som en mageløs erkendelse, er ikke usårbar over for selvstændig tænkning: "Al Umiddelbarhed er trods sin illusoriske Tryghed og Ro Angest«. Hans såkaldt »menneskelige « er et meget tvivlsomt begreb, som hverken kan holde stand mod den indre splidagtighed, (da menneskets "naturlige « behov meget ofte udelukker hinanden) ${ }^{17}$ eller mod indflydelser udefra på mennesket. Det levende ord kan lige så vel anvendes som forføringsmiddel til umenneskelighed som til menneskelighed, hvis ikke den der anvender det

16. SV, 15,84 .

17. jvf. Kierkegaard: „Fortvivlelsens Døen omsætter sig bestandigt i en Leven. Den fortvivlede kan ikke døe; saa lidet som Dolken kan dræbe Tanker, saa lidet kan Fortvivlelsen fortære det Evige, Selvet, der ligger til Grund for Fortvivlelsen, hvis Orm ikke døer, og hvis Ild ikke udslukkes. Dog er Fortvivlelse just en Selv-Fortærelse, men en afmægtig Selv-Fortærelse, der ikke formaaer hvad den selv vil. Men hvad den selv vil er at fortære sig selv, hvilket den ikke formaar ... Dette er det Hidsende ...« SV,15,78. 
samtidig skærper sine tilhøreres kritiske sans; og så er det jo ikke det levende ord mere. Grundtvig havde ikke vor tids erfaring for, hvorledes det levende ord kan misbruges i ideologers mund, men det legitimerer ikke hans bestandige trang til at berolige sine meningsfæller mod den kritiske refleksion, som Kierkegaard repræsenterede.

Hvis den kierkegaardske dialektik er en sygdom i sindet, så er den grundtvigske veltalenhed overfladiskhed, som ikke hindrer refleksionens tvivl og angstens foruroligelse, uden højst momentant. Grundtvigs folkeliggørelse er ikke det modsatte af fremmedgørelse, fordi den ikke tager hensyn til refleksionen. Folkeliggørelsen er en flugt ved poesiens, idealiseringens hjælp, som standser tvivlen allerede ved dens fremkomst. Fremmedgørelsens problem er at finde et selv i kierkegaardsk forstand. Først da kan der blive tale om et fællesskab af selvstændige individer, som ikke blot søger fællesskabet som en sekterisk loge til gensidig opbyggelse og fordømmelse af anderledes tænkende, men som er tilstedeværende i fællesskabet som enere. Grundtvig kunne forkynde visionen om »de levendes land «, »landet bag hav« og bibringe sin menighed troen på et sådant land som frelse fra »dødningehjem «, og det er muligt, at denne forkyndelse har kunnet bringe visse af tilhørerne over eksistensens dødvande; men kun for virkeligt poetiske naturer, der ved at åbne sig for digtet bliver en slags medskabere af dramatikken, kan sådanne billeder få eksistentiel betydning. Kierkegaard lærer os, at det væsentlige ikke er at tro på en sådan utopi om, at alt skal blive bedre engang, men at troen netop er at kaste sig ud i de 70.000 favne hav, som er fortvivlelsen ved at ville blive et selv, når man er afdød $\mathrm{i}$ » ødningehjem«. Kierkegaard lover ikke, at det er muligt at nå de levendes land, men han giver formodning om, at det er muligt $\mathrm{i}$ det mindste at nå frem til at kunne skimte landet, og landet er Kristi inderlighed; men kun gennem svære kampe med dæmonerne i dødsriget er det muligt. Det er denne kamp, han forelagde i sine værker, og som han brændte sig selv op i.

Grundtvig veg uden om denne kamp med dødsrigets dæmoner. Et sted taler han om døden som »den fuldkomne Tomhed og Magtesløshed, altsaa den virkelige Af-Magt«, men »hvad Døden i Grunden er, vil jeg naturligvis ligesaalidt paatage mig at forklare, som hvad... Helvede i Grunden er, thi det var det Samme, som 
at ville maale det Bund-Løse, som fornuftigvis kun kan skee ved at styrte sig selv deri, og dertil er det unægtelig dumt at lade sig overtale. Det Vovestykke overlader jeg da til dem, der har et Liv at miste, jeg har kun et at søge, og det, ved jeg, findes ikke i Dødens bundløse Afgrund, som det skal være mig inderligt kjært aldrig at gjøre nærmere eller nøiere Bekjendtskab med, end det, desværre alt er sket«.18

Grundtvigs kærlighed til alt, som er liv og fylde, gav sig udslag i de voldsomme visioner af modsætningen mellem liv og død, fylde og tomhed, men hans poesi giver hans forhold til døden karakter af escapisme eller fortrængning - og gør dermed hans opbyggelighed neurotisk. Poetiske billeder løser ikke fremmedgørelsens problem, som er afdøen fra livet på grund af refleksion, fordi den skeptiske refleksion også nedbryder det, som er de poetiske syners styrke: den momentane fortryllelse. Denne side af menneskelivet - den skeptiske - undveg Grundtvig; for ham var livet de umiddelbare livsytringer, døden den uendelige refleksion, selvrådigheden, som gør mennesket splidagtigt. Derfor holdt han krampagtigt refleksionen fra livet - $\mathrm{i}$ hvert fald som det synes udadtil - turde ikke »styrte sig selv deri«, men overlod den til én, som havde »et Liv at miste«. Det havde Kierkegaard; han kastede sig da også ud $\mathrm{i}$ »det Bund-Løse « og mistede livet i umiddelbarhed. ${ }^{19}$

Den kierkegaardske sygdom er dæmoniens, indesluttethedens, således som han selv har beskrevet den i »Begrebet Angest«, men det er en sygdom, som følger med oplysning om menneskelivet med deraf følgende selvfordybelse og relativeringsevne - et umiddelbart menneske får pludselig flere fortolkningsmuligheder for sin tilværelse og skal selv vælge sin egen. Grundtvigs tanker om folkeliggørelse, som gav sig udslag i højskolebevægelsen, var netop at bringe så mange som muligt oplysning om menneskelivet og derigennem skærpe deres skeptiske sans, som følger med indblikket i menneskesindets dybder. Det synes derfor, som om det grundtvigske kulturprogram i sig bærer kimen til det kierkegaardske problem: fremmedgørelsens fortvivlelse i indesluttethe-

18. Theologisk Månedsskrift, 2. bd. Kbh. 1825, s. $119 f$.

19. "Naar Døden er den største Fare, haaber man paa Livet; men naar man lærer den end forfærdeligere Fare at kjende, haaber man paa Døden. Naar saa Faren er saa stor, at Døden er blevet Haabet, saa er Fortvivlelse den Haabløshed end ikke at kunne døe«. SV,15,77. 
den. Grundtvig har blot ikke skuet dybt nok i mennesket eller i det mindste ikke turdet fortælle, alt hvad han så. På det punkt var Kierkegaard forud for sin tid, han foregreb dybdepsykologien.

Grundtvigs betydning er at stå som repræsentant for den humanisme, der betoner fællesskabets værdi; men i en epoke som vor, der skærper menneskets refleksionsevne ved at lægge vægten på den intellektuelle uddannelse, må den grundtvigske opbyggelighed suppleres med Kierkegaards skepticisme og skarpere definitoriske energi, hvis opbyggeligheden skal blive troværdig og dermed også holdbar. Kierkegaard prisgiver humanismen ved at nå frem til uforeneligheden mellem det menneskelige og det kristelige; han indeslutter mennesket $\mathrm{i}$ opgaven med at finde et selv og river det derved ud af fællesskabet. ${ }^{20}$ Indesluttetheden var hans egen begrænsning og tragedie, og den er det kierkegaardske livssyns ufuldkommenhed.21 Grundtvig kan minde os om, hvad der går tabt, hvis medmenneskeligheden glemmes i spekulation over selvet, fordi han forkynder en vital livsform i harmoni med tradition, venner og familie. Kierkegaard har gennemtænkt, hvilken refleksion, der må ligge til grund for en sådan livsform, om den ikke skal bestå på bekostning af perspektivet og blive manisk og humorforladt. De betonede hver sin side af den menneskelige bevidstheds virksomhed: den introverte og den ekstroverte, uden at nogen af dem formåede at forene de to sider i én og samme person; derfor det stærke modsætningsforhold mellem dem - de har måske instinktivt fornemmet, at de var hinandens manglende halvdel.

I dag bliver flere og flere lige nøjagtigt tilstrækkeligt oplyste til at kunne tro sig "frigjorte « fra de traditionelle fællesskabs- og autoritetsformer: kirke, ægteskab, den offentlige mening, tradi-

20. »Denne Skjulthed er just noget Aandeligt, og et af Betryggelses-Midlerne for at sikre sig at have ligesom bag Virkeligheden et Indelukke, en Verden udelukkende for sig selv, en Verden, hvor det fortvivlede Selv rastløs og tantalisk er beskjæftiget med at ville være sig selv« (sst. 127).

21. Kan f.eks. føre til foragt for det pulserende u-åndelige liv: "De rent pjattede U- og Med-Mennesker føle i den Grad ingen Trang til Eensomhed, at de, ligesom Selskabsfuglene strax døe, blot de et Øieblik skulle være ene; som et lille Barn maa visses i Søvn, saaledes behøve disse det Selskabeliges beroligende Vissen for at kunne spise, sove, bede, forelske sig osv.« (sst. 119). 
tion, f.eks.; der mangler blot det lille gran af yderligere oplysning, som gengiver disse traditioner den forliste umiddelbare værdi for disse mennesker, hvadenten de kalder sig fremmedgjorte eller ny-radikale, det er den proces, Kierkegaard kaldte for »gentagelsen« eller »uendelighedens dobbeltbevægelse«. Her har Grundtvig og højskolen nok stadig en berettiget funktion, og heri ligger muligheden for en kierkegaardsk inspiration i højskolen.

Men hvis den grundtvigske humanisme skal overleve i fremtiden, må det betones, at intet fællesskab i dag kan etableres på bekostning af refleksionstrangen; at vejen til det grundtvigske går gennem Kierkegaards individuationsproces: Kierkegaard først og Grundtvig så.

Benyttede forkortelser:

Korspr.:

Kors-Prædikener fra Tiden 1838-1866. I Udvalg ved N. Clausen-Bagge. Kbh. 1925.

Fredr:

Prædikener af N. F. S. Grundtvig i Frederiks-Kirken 1832-39. Udvalg v/C. J. Brandt. 1875.

EP:

Søren Kierkegaard: Efterladte Papirer. Kbh. 1869-81. I-IX. Udg. af H. P. Barfod og H. Gottsched.

Pap:

Søren Kierkegaard: Papirer. Udg. af P. A. Heiberg og V. Kuhr. Kbh. 1909-48. I-XI.

SV:

Søren Kierkegaard: Samlede Værker. I-XX. 3. udg. Kbh. 1964. 